\title{
RISK FACTORS AND SEROPREVALENCE OF HEPATITIS C ANTIBODY IN MOTHERS AND THEIR PRE-SCHOOL AGE CHILDREN IN ILORIN.
}

\author{
Agbede, 0. O. ' Iseniyi, J. 0.', " Kolawole, O. M. ${ }^{3}$, Ojnawo, A.
}

\begin{abstract}
'Department of Medical Microbiology and Parasitology, University of Ilorin, Kwara State. ${ }^{2}$ Department of Haematology, University of Mlorin Teaching Hospital, Ilorin, Kwara State. ${ }^{3}$ Department of Microbiology, University of Ilorin, P.M.B 1515, Ilorin, Kwara State, ${ }^{2}$. Department of pediatrics and child health, University of Ilorin Teaching Hospital, Llorin Kwara Nigeria.
\end{abstract}

Corresspondence to : Kolawole, O.M., Tel-23408060088495 E-mail: tomak74@yahoo.com.

\section{ABS TRACT}

In the tropics, hepatitis $\mathrm{C}$ virus (HCV) seroprevalence ranges from $<0.2 \%$ in whole Africa. Mother-to-infant transmission of $\mathrm{HCV}$ thongh relatively low, have been reported worldwide and transmission may be intrauterine, intrapartum and post-natal. A descriptive seroepidemiologic study of hepatitis $\mathrm{C}$ virus and their associated risk factors have been conducted among pairs of mother and child of pre-school age attending the "well child" clinic of the University of Ilerius Teaching Hospital and the inimunization clinic of the children specialist hospital, Ilorin. Sera of $70 \%$ mother/child pairs were susyerted to Enzyme-Linked Immunoabsorbent Assay (ELISA) for the defection of antibodies firected against the core and structural proteins of hepatitis $\mathrm{C}$ viros (anti- $\mathrm{ECV}$ ).

Anti-HCV prevalence of $1.4 \%$ was seen among mothers while none of the children was insitive $^{3}$ for anti-HCV. Scarification appeared to be the most significant risk factors that could passibly contribute to the transmission of $\mathrm{HCV}$ among the subjects. The only mother positive for anti-HCV antibodies had tribal mark scarification while her 5-year old baby who bad no tribal mark was negative.

Vaccination has been effective in reducing the incidence of hepatitis $B$ and attending complications of onset of bepatocellular carcinoma later in life; but preventive measures against hepatitis $C$ virus are not yet available

\section{INTRODUCTION}

Over the past decade, hepatitis $\mathrm{C}$ virus $(\mathrm{HCV})$ infection has risen from an obscure disease into a public heath problem all around the world. At presert, there are an esmated 170 million $\mathrm{HCV}$ carriers worldwide most of whan are thought to be - the developing countries (!). Like the HBV -:ziion, HCV infection may be trasamed xaredly by transfusion of blood and blood croducts. intravenous - drug abuse and unsafe injections. However, in $40-45 \%$ of $\mathrm{HCV}$ infections, no obvious parenteral exposure have been identified (2). The acute HCV infection is commonly asymptomatic but leads to chronic hepatitis in up to $80 \%$ of individuals. This is the highest rate of chronicity of the hepatotrophic viruses occurring in adults and is striking when compared to $\mathrm{HBV}$ infections that becomes chronic in only $5 \%$ to $10 \%$ of infections occurring in adulthood (3).

Vertically transmitted infection becomes chronic in the majority of paediatric cases, as in adult cases. The ultimate outcome of neonatal infection remains largely unknown because of the lack of data from long term longitudinal studies of infected children (4). Mother-to-child transmission rate of hepatitis $\mathrm{C}$ virus (HCV) is low, less than $10 \%$ in women not co-infected with HIV. Due to 
the fact that most published studies have included a small number of HCV-RNA positive children $(n<10)$, the transmission risk factors remain still unclear. Invasive procedures, such as aminocentesis or use of forceps, could increase the risk of transmission (5). In Nigeria, where hepatitis $B$ virus infection is hyperendemic, the impact of chronic hepatitis $\mathrm{C}$ virus infection has not been adequately elucidated most especially in mothers and their pre-school age children. This study was therefore aimed at finding the seroprevalence of $\mathrm{HCV}$ and their associated risk factors among pairs of mother and child of pre-school age attending the "well child" clinic of the University of Ilorin Teaching Hospital and the immunization clinic of the Children Specialist Hospital, Ilorin.

\section{MATERIALS AND METHODS}

Subjects

Seventy (70) pre-school age childen attending the "WELL CHILD" Clinic in the University of llorin Teaching Hospital and the Children Specialist Hospital (Center Igboro) in Ilorin and their mothers were randomly recruited for this study. Children attending these clinics in the company of other relatives and those above five years of age were exempted from this study.

Subjects were verbally informed of the study. A questionnaire was used to obtain personal data such as age and possible modes of transmission of $\mathrm{HCV}$ or risk factors such as history of previous blood transfusion, history of circumcision, history of jaundice, history of use of unsterile needles, history of HBV vaccination and history of scarification (Tribal marks).

Serum samples were cbtained from mothers and also from their children by venepuncture and stored frozen in aliquots at $20^{\circ} \mathrm{C}$. Anti-HCV was detected using third generation enzyme linked immunoabsorbent assay
(ELISA) kit (Ortho diagnostics Raritan. New Jersey USA). A repeat ELISA test was performed on each positive anti-HCV sample, in order to eliminate false positivity. Results were regarded as positive after a repeat positive ELISA test.

The results were subjected to statistical analysis using EPI-Info Version 6 Software package. Bar Chart and Cross tabulation tables were done. The critical level for statistical significance was set at $5 \%$ confidence level using the chi-square analysis.

\section{RESULTS}

The age distribution of children whose mothers participated in this study is shown in figure 1 . Of the 70 respondents about $4.3 \%$ of the children are within the age of less than $1,24.3 \%$ within the age of $1.31 .4 \%$ within the age $2,21.4 \%$ within the age 3. $15.7 \%$ within age 4 and $2.9 \%$ within age 5 . Of the respondents, $1(1.43 \%)$ mother was positive for anti-HCV antibodies while 69 (98.57\%) was negative. It is interesting to note in this study that none $(0 \%)$ of the children was positive for antiHCV antibodies (Table 1). The possible modes of transmission of risk factors and prevalence rates are shown in Tables 2 and 3. In the case of the only mother positive for anti-HCV antibodies, results indicated that the history of circumcision; history of scarification (tribal marks) and history of previous use of unsterile needles were the associated risk factors linked with her anti-HCV antibodies positivity (Table 2). This finding statistically were significant with $P$ values of $0.0411,0.0163$ and 0.0425 respectively (Table 3 ).

However, no significant association statistically were found between $\mathrm{HCV}$ Seropositivity in the only positive mother with history of previous blood iransfusion, history of jaundice and history of $H B V$ vaccination [P values of $0.758,0.758$ and 0.717 respectively] (Table 3). 


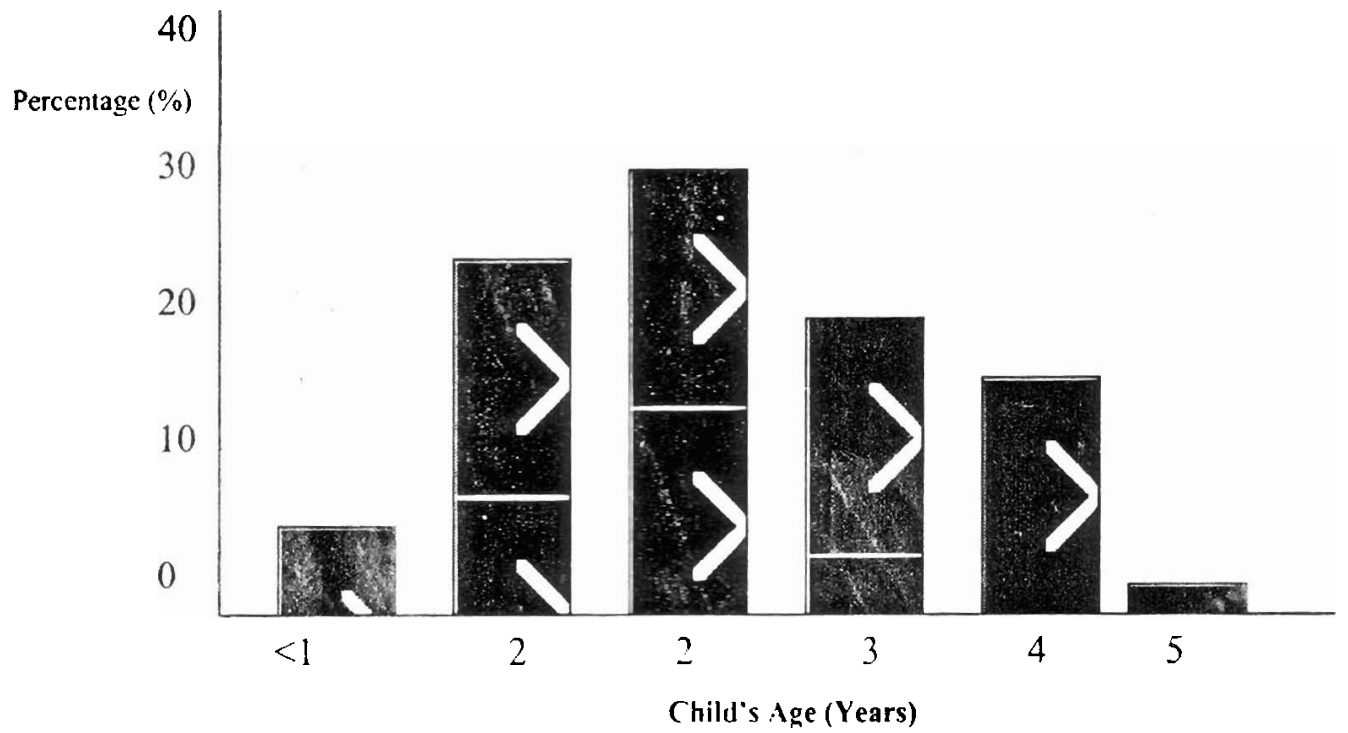

Figure 1. Age distribution of children of mothers used nn this study.

This bar chart shows the age distribution of children whose mother participated in this study. About $4.3 \%$ of the children are within the age of less than $1.24 .3^{\circ}$ s $w:$ hin the age of $1,31.4 \%$ within the age $2,21.4 \%$ within age $3,15.7 \%$ within age 4 and $2.9 \%$ within agc 5 .

Table 1 Prevalence of antibodies to $\mathrm{HCl}$ (anti-H( $\mathrm{V}$ ) in relation to mother and child.

\begin{tabular}{lcc}
\hline HCV Ab & Mother & Child \\
\hline Positive & $1(1.43 \%)$ & $0(10 \%)$ \\
Negative & $69(98.57 \%)$ & $70\left(100^{\circ} \circ\right)$ \\
Total & $70(100 \%)$ & $70\left(100^{\circ} \%\right)$
\end{tabular}

Table 2 Description of the various modes of $\mathrm{HCV}$ transmission and prevalence rates in mothers .

\begin{tabular}{|c|c|c|}
\hline Mode & anti-HCV Positive $(n=1)$ & Percentage $\%$ \\
\hline Histery of preveus jooc :ransfusion & 0 & 0 \\
\hline History of Circums!sion & 1 & 100 \\
\hline History of Jaundice & 0 & 0 \\
\hline History of $H B V$ vaccination & 0 & 0 \\
\hline \multirow[t]{2}{*}{$\begin{array}{l}\text { story of Tribal Marks (Scarification } \\
\because \text { sory of Usc of unsterile necdles }\end{array}$} & 1 & 100 \\
\hline & 1 & 100 \\
\hline
\end{tabular}

* where $n$ is the total number anti-HCV posituve mothers 


\begin{tabular}{lll}
\hline Risk Factor & Chi-square 5\% C.I \& P values & Comments \\
\hline History of blood transfusion & $\mathrm{P}=0.758$ & $\begin{array}{l}\mathrm{P}>0.05 \\
\text { There is no statistically } \\
\text { significant difference }\end{array}$ \\
History of Circumcision & $\mathrm{P}=0.0411$ & $\begin{array}{l}\mathrm{P}<0.05 \\
\text { There is statistically signifivant } \\
\text { difference }\end{array}$ \\
History of Jaundice & $\mathrm{P}=0.758$ & $\begin{array}{l}\mathrm{P}>0.05 \\
\text { There is no statistically }\end{array}$ \\
History of HBV vaccination & $\mathrm{P}=0.717$ & $\begin{array}{l}\text { significant difference } \\
\mathrm{P}>0.05\end{array}$ \\
Tistory of Tribal Marks & $\mathrm{P}=0.0163$ & $\begin{array}{l}\text { There is no statistically } \\
\text { significant difference } \\
\mathrm{P}<0.05 \\
\text { There is statistically significant } \\
\text { difference }\end{array}$ \\
(Scarification) & $\mathrm{P}=0.0425$ & $\begin{array}{l}\mathrm{P}<0.05 \\
\text { There is statistically significant } \\
\text { difference }\end{array}$ \\
History of use of unsterile & &
\end{tabular}

* C.l. means confidence interval.

\section{DISCUSSION}

Hepatitis $\mathrm{C}$ virus (HCV) belongs to the Flavi family and it is a RNA virus with prevalence rate in most countries of less than three (3) percent (6). Hepatitis $\mathrm{C}$ virus plays an important role in the causation of hepatocellular carcinoma (7). In this study, ages of children screened for hepatitis $C$ falls between less than 1 and 5 years with children within age 2 having the highest percentage of $31.4 \%$ and children of age 5 having the lowest percentage of $2.9 \%$ (Figure 1). This age group is in consonance with the work done by (8) whose study determined the age wise prevalence of Hepatitis $C$ virus in children under five years and analysed the relative importance of horizontal or vertical transmission.

In this study, of all the children screened for $\mathrm{HCV}$ anti-bodies, none was positive for antiHCV. However, only 1 mother was found positive for anti-HCV (Table 1). It is interesting to note that of all the risk factors for the transmission of $\mathrm{HCV}$ infection investigated in this study, the only positive mother had history of circumcision, tribal mark and history of usage of unsterile needle for injection in the past (Tables 2 and 3). This result revealed that the prevalence of hepatitis $\mathrm{C}$ infection in this environment is low. This finding is at variance with the result in the work done by (9) who reported $5 \%$ prevalence of antibodies to hepatitis $\mathrm{C}$ virus among normal blood donors and multi-transfused sickle-cell anaemia patients in the same environment.

The plausible reason for this differences could be in the sensitivity of the kits used in both studies. In this srudy, the third generation ELISA kit was used as against the second generation ELISA kits used in the work done by (9). Intravenous drug abuse, haemophila and homosexuality have been identified as high risk factors for hepatitis C virus transmission (10). These same risk factors have been associated with HBV infection. Furthermore, it has been reported that rates of transmission varied from one study to another probably because the risk of transmission varies in different population of women studied. Socio-cultural factors such as tribal markings by 
scarification and female genital circumcision are not common in the part of the world except in some African societies. These socio-cultural practices are often done by the use of scientifically unsterilized devices. It is plausible to suggest that engagement in these activities as verified in the singular case that was positive for HCV antibodies could have exposed this person to infection with Hepatitis $\mathrm{C}$ virus.

In summary, prevention remains the key for HCV transmissions. Older children and mothers require education about high-risk behaviours. Prevention of perinatal transmission should also be targeted. HCV infection occurs in children and is frequently less severe or more prolonged. Children might have a better response rate to therapy, but this is based upon very small and uncontrolled studies. Education is important to prevent transmission of HCV infection to adolescents and newborn (11).

\section{REFERENCES}

1) Maddawa V., Burgess C., Drucker E., (2002). Epidemiology of Chronic hepatitis C infection in Sub-Saharan Africa. Lancet infectious diseases (2002). 2:293-302.

2) Alter, H. J., Margolis, H. S., Krawczyniski, K., et-al., (1989). Clinical outcome and risk factors associated with hepatitis $C$ in the United States. Hepatology (1989). 10:581

3) Yano, M., Yatsuhashi. H.. Inove, O., et al, (1993). Epidemiology and Long term prognosis of HCV in Japan. Gut. 1993: 34 (2 Suppl.): 13-16.

4) Jonas, M. M. (2000). Hepatitis $C$ in children. In Hepatitis C, Liang, T. J. and Hoofnagle, J. H. eds. Biomed. Res. Rep. 2000;
San Diego, C. A. Academic Press, Pp. 389404.

5)

Okamoto, M., Nagata, I., Murakami, J., Hino, S., Shiraki, K. (1999). Shift in the buoyant density of hepatitis $\mathrm{C}$ virus particles in infants infected by mother-to-infant transmission. Pediatr. Int. 1999; 41:369-373.

6) Kuhnl, P., Seldl, S., Strangel, W., Beyer, J., et. al., (1989). Antibody to Hepatitis C virus in German blood donors. Lancet. 1989: ii:3234.

7) Briux, J., Barrera, J.M., Calvet, $X$., Ercilla, G., et. al., (1989). Prevalence of antibodies to hepatitis $C$ virus is Spanish patients with hepatocellular carcinoma and hepatic cirrhosis. Lancet. 1989: 2:1004-1006.

8) Chekravati, A., Rawat, D., Jain, M. (2005). A Study on the perinatal transmission of the hepatitis B virus. Indian. J. Med. Microbiol. 2005 Apr; 23 (2): 128-130.

9) Adéwuyi, J.O. (1996). Prevalence of antubodies to hepattis $C$. Virus among patients in Nigeria. Tropical Doctor 1996:26:29-30.

10) Emnet, B. K., Kent, G. B. (1993). Hepatitis $A$ through $E$ Distinguishing the etiologic agents. Modern medicine of the Middle East. Vol.10: Aug. 1993. pp 23-25.

11) Rosenthal, P. (1998). Centers for Disease Control and Prevention, "Hepatitis C. Diagnosis, Clinical Management Prevention Chronic HCV infection in children", Live Satellite Video Conference/Public Health Training Network, 1998. 